\title{
Effect of Illite on Growth Characteristic and Antioxidant Enzyme System
}

\section{of Rice under Cadmium Stress}

\author{
Chongmei She ${ }^{1, a}$, Huifen Liu ${ }^{1, b}$, Jianchao Hao ${ }^{1, c}$, Rui Wang ${ }^{1, d}$, Chunlin Li ${ }^{1, e}$ \\ ${ }^{1}$ College of Agronomy and Resources \& Environment; Tianjin Engineering Research Center of \\ Agricultural Ecological \& Remediation; Tianjin Agricultural University, Tianjin 300384, China; \\ aemail: dzxydlxscm@163.com, bemail:paula913@126.com, corresponding author, 'email: \\ qqhjc1980@tom.com, demail: 1047951695@qq.com, eemail:1072446762@qq.com
}

KEYWORDS: Cadmium Stres, Rice, Illite

ABSTRACT: Nine combinations of illite $\left(0,5,10 \mathrm{~g} \cdot \mathrm{L}^{-1}\right)$ and cadmium $\left(0,2.5,5 \mathrm{mg} \cdot \mathrm{L}^{-1}\right)$ were set, and the hydroponics was adopted in this experiment to explore the effect of illite on the rice growth characteristics under $\mathrm{Cd}$ stress, including chlorophyll content, net photosynthetic rate, plant biomass, and the antioxidant enzyme (SOD, POD and CAT) activities. The results showed that: (1) without adding illite, under severe cadmium stress $\left(5 \mathrm{mg} \cdot \mathrm{L}^{-1}\right)$, the activity of antioxidant enzymes (SOD, POD, CAT) increased, chlorophyll content, net photosynthetic rate and the biomass decreased significantly $(\mathrm{P}<0.05)$, but no significant effect on rice growth and antioxidant enzyme system was observed under mild cadmium stress $\left(2.5 \mathrm{mg} \cdot \mathrm{L}^{-1}\right)$. (2) without cadmium stress, leaf chlorophyll content, net photosynthetic rate and seedling biomass showed no significant difference between the treatment of adding illite of $5 \mathrm{mg} \cdot \mathrm{L}^{-1}$ and $10 \mathrm{mg} \cdot \mathrm{L}^{-1}$, implying that illite had no obvious influence on the growth of rice; (3) Under severe cadmium stress, adding illite obviously reduced the cadmium toxicity to chlorophyll, improved the photosynthetic rate and increased the biomass.

\section{Introduction}

Heavy metal cadmium can be accumulated by organism, enters the body through the food chain, and causes chronic poisoning, threatening human health and the environment security. Rice is one of the important crops, almost half the population in the world's main food resource. Over the past 20 years in China, the problem of excessive levels of heavy metals in rice is increasingly prominent. Department of Agriculture survey found that $6.06 \times 10^{5} \mathrm{hm}^{2}$ farmland was polluted, accounting for about $20 \%$ of the total area of investigation; Among the total area of polluted farmland, the heavy metal polluted area accounted about more than $80 \%$, especially $\mathrm{Pb}^{2+}, \mathrm{Cd}^{2+}$, $\mathrm{Hg}^{2+}, \mathrm{Cu}^{2+}$ and their compound pollution ${ }^{[1]}$. About $10 \%$ common commercially available rice on the market in China was cadmium polluted ${ }^{[2]}$. As its high mobility and high toxic, cadmium has been widely known as one of the most threatening toxic heavy metals ${ }^{[3]}$. High concentrations of $\mathrm{Cd}^{2+}$ induced excessive reactive oxygen species, damaged and interfered with the normal metabolism of cells ${ }^{[4]}$.Plant can resist cadmium stress through various mechanisms, for example, antioxidant systems to clear reactive oxygen species ${ }^{[4,5]}$. SOD can effectively remove plants oxygen free radicals, $\mathrm{POD}$ can reduce excessive peroxides in plant and $\mathrm{CAT}$ can eliminate excess hydrogen peroxide $\left(\mathrm{H}_{2} \mathrm{O}_{2}\right)$ in the cell and protect the structure of membrane ${ }^{[6,7]}$.

Currently, lots of effect of cadmium stress on rice growth has been researched, and some clay minerals have been used in the removal of heavy metals in soil and wastewater. Illite is a kind of rich potassium of layered hydrosilicate clay mineral, due to its small particle size, larger specific surface area and colloidal properties, as a low-cost adsorbent, it has been applied to industrial wastewater, cyanobacteria bloom and other environmental fields ${ }^{[8]}$. The heavy metals in wastewater are removed by illite through ion exchange ${ }^{[9]}$. The research on illite application in crop growth under heavy metal stress has little reported. This study adopted hydroponics experiment to research the effect of illite on the growth and antioxidant enzyme system of rice seedling under Cd stress, to explore if illite could relieve the cadmium stress in rice seedling stage. 


\section{Materials and Methods}

\section{Experimental Materials}

The illite clay used in this study was purchased from Xintai non-metallic mineral co., LTD, Hebei, the rice variety was "Jinyuan 45" supported by Institute of Crop Sciences, Tianjin Academy of Agricultural Sciences. Ceramic cylinders $(13 \mathrm{~cm}$ in diameter, $10 \mathrm{~cm}$ in height, volume of $1 \mathrm{~L}$ ) with seven uniform holes lid were used in this hydroponic pot experiment.

\section{Experimental Design}

The experiment was carried out in the key laboratory of Environmental Science Department, Tianjin Agricultural University. Rice seeds were disinfected with $75 \%$ ethanol for 5 minutes and then sterilized with $0.1 \%$ sodium hypochlorite solution for 10 minutes. Seeds were germinated in plastic tray in constant temperature incubator with temperature of $35^{\circ} \mathrm{C}$ and humidity of $90 \%$, seedlings were raised for 20 days in vermiculite cultures then transplanted to hydroponic pots raised with rice hydroponic formula recommended by the International Rice Research Institute, with $\mathrm{N}, \mathrm{P}$ and $\mathrm{K}$ concentration 40,10 and $40 \mathrm{mg} \cdot \mathrm{L}^{-1}$, respectively. Nutrient solution $\mathrm{pH}$ was adjusted with $\mathrm{NaOH}$ to about 5.5 every five days after five hours aeration.

A completely randomized design was used, with 3 replications and 9 combined treatments of $\mathrm{Cd}\left(0,2.5,5 \mathrm{mg} \cdot \mathrm{L}^{-1}\right)$ and illite $\left(0,5,10 \mathrm{~g} \cdot \mathrm{L}^{-1}\right)$, consistent rice seedlings were selected to make up 27 pots, 6 plants per pot. The 9 treatments are noted as T1(Cd-0,illite-0),T2(Cd-0,illite-5),T3(Cd-0,illite-10),T4(Cd-2.5,illite-0),T5(Cd-2.5,illi-te-5),

T6(Cd-2.5, illite-10),T7(Cd-5,illite-0), T8(Cd-5, illite-5), T9(Cd -5,illite-10). Chlorophyll content, photosynthetic rate and the activity of SOD, POD and CAT were measured on the $14^{\text {th }}$ day, $21^{\text {st }}$ day, $28^{\text {th }}$ day, $35^{\text {th }}$ day, the biomass $\left(\mathrm{g} \cdot\right.$ pot $\left.^{-1}\right)$ were measured after the harvest.

\section{Measurement Methods}

Superoxide dismutase (SOD) activity was determined according to the method of nitroblue tetrazolium (NBT) light reduction, peroxidase (POD) activity was monitored according to the method of guaiaco, catalase (CAT) activity was assayed according to the method of ultraviolet spectrophotometry ${ }^{[10,11]}$. The whole plant rinsed with deionized water, dried in an oven at $105{ }^{\circ} \mathrm{C}$ for 30 minutes and $70{ }^{\circ} \mathrm{C} 48 \mathrm{~h}$, then weighed. The chlorophyll content was determined by SPAD-502 chlorophyll meter, net photosynthetic rate (Pn) was monitored by CI-340 photosynthetic apparatus.

\section{Statistical Analysis}

All data were processed using Microsoft Excel 2013, and each value of mean and S.D.(standard deviation) in the tables represents 3 replications of measurements. The assessment of effects of Cd stress, illite application and their interaction on rice seedling growth and some physiological indices were made using ANOVA and GLM procedures of SPSS16.0 software, followed by Duncan test for multiple sample comparison.

\section{Results and Analyses}

\section{Effect of different Cd and illite treatments on activities of SOD,POD and CAT of rice leaf}

The influence of different treatments of illite and $\mathrm{Cd}^{2+}$ on SOD, POD, CAT activity of rice leaf was shown in Table 1. The SOD activity in T7 was 1.55 times, 1.92 times, and 4.39 times higher than $\mathrm{T} 1$ on the 14th day, 21st day and 35th day, respectively, but no significant difference was found between $\mathrm{T} 4$ and $\mathrm{T} 1$, indicating that only severe $\mathrm{Cd}^{2+}$ stress $\left(5 \mathrm{mg} \cdot \mathrm{L}^{-1}\right)$ had significant influence on SOD activity. No significant difference existed in SOD activity among treatments of T1, T2 and T3, implying that illite application had no significant effect on SOD activity. As shown in Table 1, there existed no significant differences in POD activity between T1 and T4, T4 and T7, among different illite treatments (T1,T2 and T3; T4, T5 and T6; T7, T8 and T9), indicating that the application of illite had little effect on POD activity of rice leaf under cadmium stress. CAT activity of rice leaf showed no obvious trend under different $\mathrm{Cd}$ and illite treatments. 
Table 1 Effects of different treatment of cadmium and illite on SOD, POD, CAT activity of rice leaf

\begin{tabular}{|c|c|c|c|c|c|c|c|c|c|}
\hline & \multicolumn{3}{|c|}{$\mathrm{SOD} \quad\left(\mathrm{U} \cdot \mathrm{mg}^{-1} \mathrm{Fw}\right)$} & \multicolumn{3}{|c|}{$\mathrm{POD}\left(\mathrm{U} \cdot \mathrm{mg}^{-1} \mathrm{Fw} \cdot \mathrm{min}^{-1}\right)$} & \multicolumn{3}{|c|}{$\mathrm{CAT}\left(\mathrm{U} \cdot \mathrm{mg}^{-1} \mathrm{FW} \cdot \mathrm{min}^{-1}\right)$} \\
\hline & $14 \mathrm{~d}$ & $21 \mathrm{~d}$ & $35 \mathrm{~d}$ & $14 \mathrm{~d}$ & $21 \mathrm{~d}$ & $35 \mathrm{~d}$ & $14 \mathrm{~d}$ & $21 \mathrm{~d}$ & $35 \mathrm{~d}$ \\
\hline $\mathrm{T} 1$ & $0.38 \pm 0.08 \mathrm{c}$ & $0.38 \pm 0.13 \mathrm{c}$ & $0.23 \pm 0.02 \mathrm{e}$ & $60.48 \pm 31.54 \mathrm{~b}$ & $58.60 \pm 14.43 b$ & $69.20 \pm 42.29 \mathrm{ab}$ & $1.38 \pm 0.53 \mathrm{abc}$ & $0.53 \pm 0.08 \mathrm{c}$ & $0.91 \pm 0.14 \mathrm{~b}$ \\
\hline $\mathrm{T} 2$ & $0.31 \pm 0.14 \mathrm{c}$ & $0.55 \pm 0.11 \mathrm{abc}$ & $0.31 \pm 0.10 \mathrm{de}$ & $79.87 \pm 21.67 \mathrm{ab}$ & $96.86 \pm 46.97 \mathrm{ab}$ & $120.17 \pm 45.38 \mathrm{a}$ & $2.69 \pm 0.64 \mathrm{a}$ & $2.16 \pm 1.48 b$ & $1.04 \pm 0.24 \mathrm{~b}$ \\
\hline $\mathrm{T} 3$ & $0.45 \pm 0.02 \mathrm{bc}$ & $0.41 \pm 0.09 \mathrm{bc}$ & $0.43 \pm 0.12 \mathrm{cde}$ & $67.34 \pm 3.15 \mathrm{ab}$ & $79.86 \pm 9.71 \mathrm{ab}$ & $72.97 \pm 31.74 \mathrm{ab}$ & $1.05 \pm 0.56 \mathrm{bc}$ & $0.61 \pm 0.72 \mathrm{c}$ & $1.05 \pm 0.15 \mathrm{~b}$ \\
\hline $\mathrm{T} 4$ & $0.50 \pm 0.13 b c$ & $0.51 \pm 0.06 \mathrm{abc}$ & $0.52 \pm 0.08 \mathrm{bcde}$ & $75.65 \pm 10.81 \mathrm{ab}$ & $65.31 \pm 28.23 \mathrm{ab}$ & $66.12 \pm 18.35 \mathrm{ab}$ & $0.78 \pm 0.58 \mathrm{c}$ & $1.34 \pm 0.61 \mathrm{bc}$ & $1.23 \pm 0.16 \mathrm{ab}$ \\
\hline $\mathrm{T} 5$ & $0.58 \pm 0.05 \mathrm{a}$ & $0.63 \pm 0.02 \mathrm{ab}$ & $0.76 \pm 0.23 \mathrm{ab}$ & $94.5 \pm 11.24 \mathrm{a}$ & $75.89 \pm 8.36 \mathrm{a}$ & $65.12 \pm 12.67 \mathrm{~b}$ & $1.03 \pm 0.15 b c$ & $1.44 \pm 0.33 \mathrm{bc}$ & $1.72 \pm 0.43 \mathrm{a}$ \\
\hline T6 & $0.48 \pm 0.08 \mathrm{bc}$ & $0.54 \pm 0.08 \mathrm{abc}$ & $0.51 \pm 0.01 \mathrm{bcde}$ & $74.29 \pm 6.95 \mathrm{ab}$ & $64.53 \pm 21.51 \mathrm{ab}$ & $75.35 \pm 13.69 \mathrm{ab}$ & $1.72 \pm 1.26 \mathrm{abc}$ & $0.57 \pm 0.28 \mathrm{c}$ & $1.03 \pm 0.14 \mathrm{~b}$ \\
\hline $\mathrm{T} 7$ & $0.59 \pm 0.08 \mathrm{a}$ & $0.73 \pm 0.23 \mathrm{a}$ & $1.01 \pm 0.27 \mathrm{a}$ & $96.96 \pm 14.19 \mathrm{a}$ & $92.27 \pm 13.69 \mathrm{a}$ & $82.7 \pm 29.99 \mathrm{ab}$ & $2.48 \pm 1.43 \mathrm{ab}$ & $5.44 \pm 1.15 \mathrm{a}$ & $1.25 \pm 0.38 \mathrm{ab}$ \\
\hline $\mathrm{T} 8$ & $0.47 \pm 0.08 \mathrm{bc}$ & $0.69 \pm 0.1 \mathrm{a}$ & $0.55 \pm 0.14 \mathrm{bcd}$ & $83.16 \pm 19.53 \mathrm{ab}$ & $91.57 \pm 23.14 \mathrm{ab}$ & $69.85 \pm 20.97 \mathrm{ab}$ & $1.80 \pm 0.71 \mathrm{abc}$ & $1.52 \pm 0.62 \mathrm{bc}$ & $1.21 \pm 0.08 \mathrm{ab}$ \\
\hline T9 & $0.39 \pm 0.17 b c$ & $0.45 \pm 0.07 \mathrm{bc}$ & $0.63 \pm 0.21 b c$ & $96.97 \pm 10.27 \mathrm{a}$ & $66.04 \pm 13.42 \mathrm{a}$ & $83.43 \pm 10.31 \mathrm{ab}$ & $1.02 \pm 0.21 b c$ & $4.05 \pm 0.89 \mathrm{a}$ & $1.64 \pm 0.48 \mathrm{a}$ \\
\hline
\end{tabular}

Note: Different small letters indicate significant differences between the treatments $(\mathrm{p}<0.05)$.

\section{Chlorophyl content and net photosynthetic rate of rice leaf under different treatments}

Table 2 Effects of different treatment of cadmium and illite on chlorophyl content (SPAD) and net photosynthetic rate ( $\mathrm{Pn}$ ) of rice leaf

\begin{tabular}{lllllll}
\hline & \multicolumn{5}{c}{ SPAD } & \multicolumn{3}{c}{ Pn } \\
\cline { 2 - 6 } & $14^{\text {th }}$ day & 21 stday & $35^{\text {th }}$ day & $14^{\text {th }}$ day & $21^{\text {st }}$ day & $35^{\text {th }}$ day \\
\hline T1 & $36.36 \pm 1.17 \mathrm{ab}$ & $39.26 \pm 3.72 \mathrm{a}$ & $42.68 \pm 0.62 \mathrm{a}$ & $8.24 \pm 1.34 \mathrm{a}$ & $10.61 \pm 0.69 \mathrm{a}$ & $8.37 \pm 1.71 \mathrm{a}$ \\
T2 & $38.10 \pm 3.07 \mathrm{a}$ & $37.94 \pm 1.95 \mathrm{ab}$ & $40.96 \pm 0.83 \mathrm{ab}$ & $8.07 \pm 0.44 \mathrm{ab}$ & $9.98 \pm 1.17 \mathrm{a}$ & $7.69 \pm 1.6 \mathrm{ab}$ \\
T3 & $36.66 \pm 0.07 \mathrm{ab}$ & $38.0 \pm 2.09 \mathrm{ab}$ & $39.54 \pm 1.85 \mathrm{bc}$ & $8.16 \pm 0.88 \mathrm{ab}$ & $10.88 \pm 1.48 \mathrm{a}$ & $6.03 \pm 2.9 \mathrm{abc}$ \\
T4 & $36.89 \pm 2.83 \mathrm{ab}$ & $37.36 \pm 0.88 \mathrm{ab}$ & $36.98 \pm 0.81 \mathrm{de}$ & $6.88 \pm 0.77 \mathrm{bc}$ & $6.59 \pm 0.62 \mathrm{bc}$ & $5.97 \pm 1.67 \mathrm{bcd}$ \\
T5 & $33.69 \pm 0.69 \mathrm{bc}$ & $33.59 \pm 1.55 \mathrm{bc}$ & $36.30 \pm 1.43 \mathrm{e}$ & $5.0 \pm 0.26 \mathrm{de}$ & $6.44 \pm 0.72 \mathrm{bc}$ & $4.3 \pm 0.78 \mathrm{cde}$ \\
T6 & $36.19 \pm 0.85 \mathrm{ab}$ & $35.88 \pm 2.95 \mathrm{ab}$ & $38.59 \pm 0.72 \mathrm{~cd}$ & $6.12 \pm 1.02 \mathrm{~cd}$ & $7.72 \pm 0.96 \mathrm{~b}$ & $5.14 \pm 1.48 \mathrm{bcde}$ \\
T7 & $32.0 \pm 1.56 \mathrm{c}$ & $30.23 \pm 4.78 \mathrm{c}$ & $29.69 \pm 0.37 \mathrm{f}$ & $4.69 \pm 0.68 \mathrm{e}$ & $3.21 \pm 1.07 \mathrm{~d}$ & $2.67 \pm 0.55 \mathrm{e}$ \\
T8 & $34.36 \pm 0.29 \mathrm{bc}$ & $35.30 \pm 1.33 \mathrm{ab}$ & $36.47 \pm 1.06 \mathrm{e}$ & $7.37 \pm 0.19 \mathrm{abc}$ & $5.13 \pm 1.28 \mathrm{c}$ & $4.10 \pm 1.04 \mathrm{cde}$ \\
T9 & $36.4 \pm 1.88 \mathrm{ab}$ & $36.08 \pm 0.3 \mathrm{ab}$ & $35.94 \pm 1.26 \mathrm{e}$ & $7.00 \pm 0.09 \mathrm{abc}$ & $6.28 \pm 1.48 \mathrm{bc}$ & $3.09 \pm 0.22 \mathrm{de}$ \\
\hline
\end{tabular}

Cadmium stress can result in biomass decreasing trough the destruction of chloroplast structure and the decrease of leaf chlorophyll content ${ }^{[12]}$. For the rice leaf chlorophyll content (SPAD), T4 was $95 \%, 87 \%$ of T1 and T7 was $77 \%, 70 \%$ of $\mathrm{T} 1$ in $21^{\text {st }}$ day and $35^{\text {th }}$ day, for net photosynthetic rate $(\mathrm{Pn}), \mathrm{T} 4$ was $83 \%, 62 \%, 78 \%$ of $\mathrm{T} 1$ and $\mathrm{T} 7$ was $57 \%, 30 \%, 35 \%$ of $\mathrm{T} 1$ on $14^{\text {th }}$ day, $21^{\text {st }}$ day, $35^{\text {th }}$ day, respectively (seen Table 2), implying cadmium stress had obvious inhibitory effect on rice leaf chlorophyll content and net photosynthetic rate. No significant difference in chlorophyll content and net photosynthetic rate of rice leaf among T1, T2 and T3, indicated that adding illite had little effect on rice growth without Cd stress, while, chlorophyll content of T6 was significantly higher than $\mathrm{T} 5$ on $35^{\text {th }}$ day under mild cadmium stress(T4,T5, T6), chlorophyll content and net photosynthetic rate in T9 was significantly higher than those of T7 under severe cadmium stress(T7, T8,T9), proving that illite could lessen the toxicity of cadmium on rice. 


\section{Effect of different $\mathrm{Cd}$ and illite treatment on biomass of rice leaf}

Table 3 Effects of different treatment of cadmium and illite on rice biomass $\left(\mathrm{g} \cdot \operatorname{pot}^{-1}\right)$

\begin{tabular}{cccc}
\hline \multirow{2}{*}{$\mathrm{Cd}\left(\mathrm{mg} \cdot \mathrm{L}^{-1}\right)$} & \multicolumn{3}{c}{ dosage of illite $\left(\mathrm{g} \cdot \mathrm{L}^{-1}\right)$} \\
\cline { 2 - 4 } & 0 & 5 & 10 \\
\hline 0 & $4.30 \pm 0.92 \mathrm{ab}$ & $4.32 \pm 0.92 \mathrm{ab}$ & $4.55 \pm 0.07 \mathrm{ab}$ \\
2.5 & $2.98 \pm 0.07 \mathrm{bc}$ & $3.22 \pm 0.48 \mathrm{abc}$ & $4.76 \pm 0.77 \mathrm{a}$ \\
5 & $1.80 \pm 0.44 \mathrm{c}$ & $3.56 \pm 0.38 \mathrm{ab}$ & $4.14 \pm 1.27 \mathrm{ab}$ \\
\hline
\end{tabular}

Mild cadmium stress had no obvious effect on biomass than the control (Cd 0), while severe cadmium stress significantly inhibited the growth of rice. The application of illite had no significant effect on rice biomass under no cadmium stress, but the rice biomass of adding $5 \mathrm{~g} \cdot \mathrm{L}^{-1}$ or $10 \mathrm{~g} \cdot \mathrm{L}^{-1}$ illite were both significantly higher than that without illite under mild or severe $\mathrm{Cd}^{2+}$ stress, which implied that illite can alleviate the toxicity of cadmium stress to rice.

\section{Discussion}

When subjected to cadmium stress, rice plant can produce $\mathrm{O}^{2-} \cdot \mathrm{H}_{2} \mathrm{O}_{2}$ and other reactive oxygen matters that damage cell macro-molecules and plasma membrane, resulting in biomass declining, unbalanced antioxidant enzyme system, and the inhibition of plant growth, even plant death $^{[13]}$. SOD, POD, CAT are all major enzymes in plant antioxidant protection system to relieve the accumulation of $\mathrm{O}^{2-}$ and $\mathrm{H}_{2} \mathrm{O}_{2}$ and reduce damage of adversity stress ${ }^{[14]}$. It is generally believed that cadmium stress can induce the expression of plant SOD, but this promotion and duration vary with treatment concentration, plant species and plant size ${ }^{[15]}$. POD activity of plant increased with the increase of $\mathrm{Cd}^{2+}$ concentration and the extension of processing time ${ }^{[16]}$.

In this study, SOD, POD and CAT activity all increased with the increased concentration of cadmium, chlorophyll content, net photosynthetic rate and biomass all decreased with the decreasing concentration of cadmium. Mild cadmium stress had no significant influence on rice growth and antioxidant enzyme system and biomass, while, severe cadmium stress significantly improved the activity of SOD, POD and CAT in rice leaf, inhibited leaf chlorophyll content and net photosynthetic rate, resulting in the decrease of biomass. The application of illite showed no notable effect on SOD, POD, CAT activity of rice leaf under without or mild cadmium stress, while, under severe cadmium stress, the chlorophyll content and biomass was higher in the treatments with illite than without illite, suggesting the inhibitory effect of illite on cadmium. No significant difference in rice biomass was found between $\mathrm{T} 5\left(\mathrm{Cd} 2.5 \mathrm{mg} \cdot \mathrm{L}^{-1}\right.$, illite $\left.5 \mathrm{mg} \cdot \mathrm{L}^{-1}\right)$ and $\mathrm{T} 6\left(\mathrm{Cd} 2.5 \mathrm{mg} \cdot \mathrm{L}^{-1}\right.$, illite 10 $\left.\mathrm{mg} \cdot \mathrm{L}^{-1}\right)$, T8 $\left(\mathrm{Cd} 5 \mathrm{mg} \cdot \mathrm{L}^{-1}\right.$, illite $\left.5 \mathrm{mg} \cdot \mathrm{L}^{-1}\right)$ and $\mathrm{T} 9\left(\mathrm{Cd} 5 \mathrm{mg} \cdot \mathrm{L}^{-1}\right.$, illite $\left.10 \mathrm{mg} \cdot \mathrm{L}^{-1}\right)$, which may attributed to the exchangeable adsorption of illite for cadmium ${ }^{[17,18\}}$.

\section{References}

[1] Hui He, Wenjing Zhou. Status and Control Strategies of Heavy Metal Contamination in Crop. Journal of Anhui Agricultural Sciences. 2013, 41( 9):4029-4031.

[2] Zefu Yi, Xing Yu, Jing Wu, et al. Advance in research of cadmium polluted soil remediation technologies. Modern Agricultural Sciences and Technology, 2014, 2 (9):251-253.

[3] Wangda Cheng, Haigen Yao, Guoping Zhang, et al. Effect of Cadmium on Growth and Nutrition Metabolism in Rice. Scientia Agricultura Sinica, 2005, 38 (3):528-537.

[4] Dixit V, Pandey V, Shyam R. Differential antioxidative responses to cadmium in roots and leaves of pea (Pisum sativum L. cv. Azad) . J Exp Bot, 2001, 52 (358):1101-1109.

[5] Zhongjun $\mathrm{Xu}$, Fan $\mathrm{Hu}$, Mingming Han, et al. Impact of Cadmium stress on genetically modified rice root and aboveground antioxidant enzyme. Jiangsu Agricultural Sciences, 2009, (6):92-94.

[6] Jing Shi, Genxing Pan, Yunsheng Xia, et al. Effects of $\mathrm{Cd}$ on different rice growth and antioxidant enzyme system. Ecology and Environmental Sciences, 2013, 22(5):832-837

[7] Mohammad Babar Ali, Hyun Sik Chun, Byung Ki Kim, et al. Cadmium-induced changes in 
antioxidant enzyme activities in rice (Oryza sativa L. cv. Donlin). Journal of Plant Biology, 2002, 45(3):134-140

[8] Xiaoming Li, Xiaowei Kou. Illite: A New Potential Clay Mineral Material. World Geology, 2000, 4(19):346-349

[9] Na Li, Fan Wang, Heng Zhao, et al. An Overview on Application of Natural Illite Clays. China Non-Metallic Mineral Industry, 2012, (2):32-36

[10] Xianzheng Zhang. Research Method of Crop Physiology, Beijing, Agricultural Press, 1992

[11] Wenbiao Shen. The suitable conditions for determination SOD activity by nitroblue tetrazolium (NBT) photoreduction method. Journal of Nanjing Agricultural University, 1996, 19(2):101-102 .

[12] Baoquan Zhao, Wan Yu, Yang Shihu, et al. Effects of Exogenous Nitric Oxide Donor SNP on Membrane Lipid Peroxidation and Activity of Antioxidant Enzyme in Rice Seedlings under Cadmium Stress. Jiangsu Journal of Agriculture Sciences, 2010, 26(3):468-475.

[13] Xin Shi, Yingming Xu, Zhonglei Xie,et al. Effects of Bentonite on Physiological and Biochemical Characteristics of Rice Seedlings under cadmium stress. Journal of Ecology and Rural Environment, 2012, 28(6):687-693

[14] Rui Long, Ming Zhang, Guangsheng Zhang, et al. Effects of Mn and Cd and Mn-Cd Combination on Growth and Physiological and Biochemical Characteristics of Elodea nutttallii. Journal of Agro-Environment Science, 2014, 33(6):1112-1117

[15] Guosheng Shao, Hassan M J, Xiufu Zhang, et al. The influence of cadmium stress on different rice genotypes growth and antioxidant enzyme system. Journal of Rice Science in China, 2004, 18(3): 239-241

[16] Radotic K, Ducic T, Mutavdzic D. Changes in peroxidase activity and isoenzymes inspruce needles after exposure to different concentrations of cadmium. Environment. Exp. Bot, 2000, 44(2): $105-113$

[17] Chunling Li, Qinyan Yue, Ying LI, et al. Adsorption and desorption of Zinc (I) and Cadmium (II) on illite. Journal of Shandong University (Natural Science), 2009, 44(11):6-11

[18] Hongping He, Jiugao Guo, Jianxi Zhuo, et al. An Experimental study of Adsorption Capacity of Montmorillonite, Kaolinite and Illite for heavy metals. Acta Petrologica Mineralogica, 2001, 20(4): 